\title{
Methyl derivatives of tetracyclic psoralen analogues: antiproliferative activity and interaction with DNA
}

\author{
Lisa Dalla Via, ${ }^{a}$ Eugenio Uriarte, ${ }^{b}$ Lourdes Santana, ${ }^{a}$ Sebastiano Marciani Magno, ${ }^{a}$ and \\ Ornella Gia*a \\ ${ }^{a}$ Department of Pharmaceutical Sciences, University of Padova, via Marzolo 5, 35131 Padova, \\ Italy \\ ${ }^{b}$ Department of Organic Chemistry, University of Santiago de Compostela, Spain \\ E-mail: ornellamaria.gia@unipd.it
}

\section{Dedicated to Professor Vincenzo Tortorella on the occasion of his "Fuori Ruolo" status}

(received 22 Dec 03; accepted 20 Feb 04; published on the web 04 Mar 04)

\begin{abstract}
A number of new tetracyclic psoralen derivatives were studied. The fourth ring is constituted by cyclopentane $(4,7$ and 9), cyclohexane $(11,15$ and 18) or benzene $(12,16$ and 20$)$ fused to either $4^{\prime}, 5^{\prime}$ or 3,4 photoreactive double bond of tricyclic furocoumarin moiety. The photoantiproliferative activity of all compounds, tested on two human tumor cell lines (HeLa and HL-60), appeared from 8 to 22 times higher than that of the well-known photochemotherapeutic drug 8-methoxypsoralen (8-MOP) in HeLa, slightly higher in HL-60. Interestingly, the evaluation of skin phototoxicity on guinea pigs evidenced a decrease in erythema induction for all compounds with respect to the drug. As regards the molecular mechanism of action, the ability to photoadd to DNA is demonstrated by isolation and characterization of the photoadducts and by the ability to give rise to interstrand cross-links for the difunctional derivatives.
\end{abstract}

Keywords: Tetracyclic psoralen analogues, antiproliferative activity, DNA interaction

\section{Introduction}

Inside the wide field of photochemotherapy the psoralens play a significant role. In particular, skin diseases characterized by hyperproliferation, such as psoriasis, are effectively treated by means of PUVA therapy (psoralen plus UVA light). ${ }^{1-3}$ Moreover, psoralens are successfully employed for the treatment of cutaneous T-cell lymphoma, a T-cell mediated disorder, by an extracorporeal photochemotherapy called photopheresis. ${ }^{4,5}$ Nevertheless, the existence of some undesired side-effects limits the therapeutic use of psoralens. Indeed, both short-term (erythema, 
hyperpigmentation) and long-term (benign keratoses, premalignant keratoses, skin cancers) undesired effects can occur. ${ }^{2}$

Between psoralens, 8-methoxypsoralen (8-MOP) constitutes the drug most widely employed, but also 5-methoxypsoralen and 4,5',8-trimethylpsoralen hold a noticeable role in photochemotherapy, even though to a lesser extent. ${ }^{6,7}$

The psoralen tricyclic moiety, due to its planarity, is able to intercalate inside base pairs of DNA. Upon UVA irradiation $(365 \mathrm{~nm})$ a photoaddition reaction between the 4',5' furan side and/or the 3,4 pyrone side double bonds and the 5,6 double bond of a pyrimidine base, generally thymine, can take place. The ability of the furan side monoadduct to absorb at $365 \mathrm{~nm}$ can allow the formation of diadducts involving two bases belonging to the opposite DNA strands. ${ }^{8}$

Many psoralen derivatives have been synthesized up to now with the aim of weakening the undesired side effects. Inside the different lines of research, the condensation of a fourth benzenic or cyclohexenyl ring to the tricyclic psoralen chromophore led to some tetracyclic moieties endowed with interesting photobiological properties. ${ }^{9-15}$ In particular, it was shown that the presence of a fourth aromatic ring caused the disappearance of the skin photosensitizing potency, evaluated as erythema induction. Furthermore, for some benzopsoralen derivatives a noteworthy increase in photoantiproliferative activity on human tumor cell lines, with respect to 8-MOP, was demonstrated. As regards the tetrahydrobenzopsoralen moiety, the most interesting derivatives showed a cytotoxic activity higher with respect to that exerted by the reference drug along with a significant decrease of skin phototoxicity. ${ }^{14,15}$ The condensation of a cyclopentane ring to the tricyclic psoralen nucleus was also reported. ${ }^{16}$ In detail, the synthesized cyclopentenepsoralen bearing the cyclopentane ring fused to the 4 ',5' double bond appears to show a slight improvement in photobiological properties, i.e. increased photoantiproliferative activity on human tumor cell line and diminished skin photosensitization, with respect to the drug 8-MOP. ${ }^{16}$

Moreover, in previous studies it was demonstrated that the introduction of methyl groups in the psoralen cromophore appeared to increase significantly its ability to photobind to DNA and, in some cases, to improve the photobiological properties. ${ }^{17-19}$

In this paper we studied the photobiological behaviour of a series of structurally related psoralen derivatives endowed with a tetracyclic nucleus and carrying two methyl groups in different positions.

In detail, the derivatives taken into consideration are characterized by the presence of a cyclopentane $(4,7$ and 9$)$, a cyclohexane $(11,15$ and 18$)$ or a benzene $(12,16$ and 20$)$ ring fused to the tricyclic psoralen cromophore. The fourth ring is condensed at the level of the furan or pyrone photoreactive double bond. Furthermore, a methyl group is linked in the 8 position along with a further methyl at the level of the $4^{\prime}, 5^{\prime}$ or 4 position of the tricyclic psoralen structure.

The photoantiproliferative activity on human tumor cell lines, the skin phototoxicity on guinea pigs and the photoaddition to DNA were evaluated in comparison with the well-known drug 8MOP. Furthermore, the isolation and characterization of furan photoadducts with thymine were reported. 


\section{Results and Discussion}

\section{Chemistry}

The studied compounds $(4,7,9,11,12,15,16,18,20)$ were obtained starting from 2methylresorcinol (1), as shown in Scheme 1.<smiles>Cc1cc(=O)oc2c(C)c3oc4c(c3cc12)CCC4</smiles>

$\uparrow \mathrm{c}$<smiles>Cc1cc(=O)oc2c(C)c(OC3CCCC3=O)ccc12</smiles>

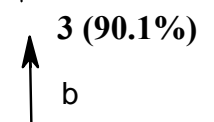<smiles>C=C(Br)COc1ccc2c3c(c(=O)oc2c1C)CCC3</smiles>

$\uparrow d$<smiles>CCCc1c(C)oc2cc3cc(C(C)C)c(C)c-3oc12</smiles>

$9(52 \%)$

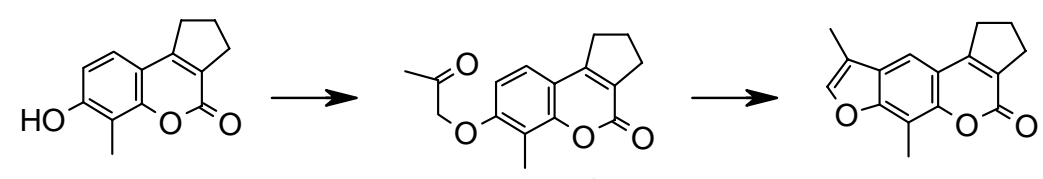

6

7

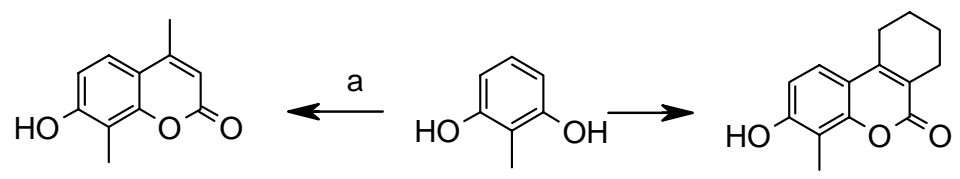<smiles>Cc1cc(OC2CCCCC2=O)c(C)c2c(C)cc(=O)oc12</smiles><smiles>CC(C)CC1CCCCC1</smiles><smiles>CC(=O)COc1ccc2c3c(c(=O)oc2c1C)CCCCC3</smiles><smiles></smiles><smiles>Cc1cc(=O)oc2c(C)c3oc4ccccc4c3cc12</smiles><smiles>Cc1coc2c(C)c3oc(=O)c4ccccc4c3cc12</smiles>

16

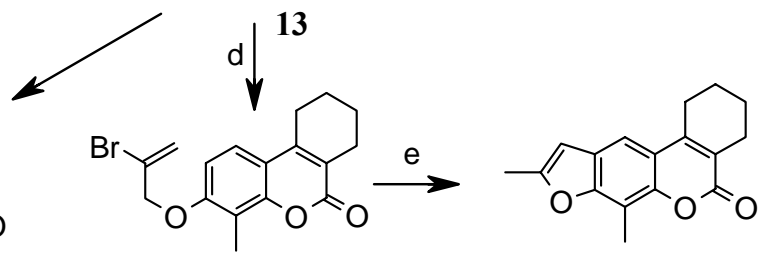

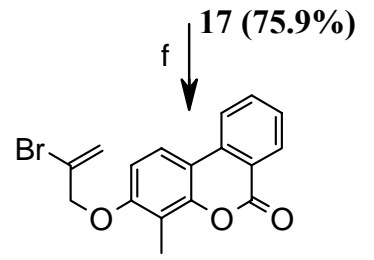

$18(57.1 \%)$

12

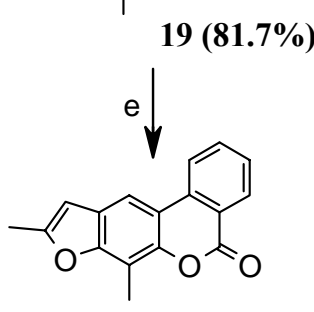

$20(52 \%)$

Scheme 1. Reagents: (a) ethylacetoacetate, $\mathrm{H}_{2} \mathrm{SO}_{4}$; (b) 2-chlorocyclopentanone; (c) $\mathrm{NaOH}$; (d) $\mathrm{K}_{2} \mathrm{CO}_{3}$, 2,3-dibromopropene; (e) N,N-diethylaniline; (f) 2,3-dichloro-5,6-dicyano-1,4benzoquinone, toluene. The yields are reported in parentheses. 
The preparation of $7, \mathbf{1 1}, \mathbf{1 2}, \mathbf{1 5}, \mathbf{1 6}$ and 18, in accordance with a general approach to the psoralen skeleton, has been described elsewhere., ${ }^{9,20,21,22}$

Pechmann condensation of compound $\mathbf{1}$ and ethyl acetoacetate afforded the corresponding hydroxycoumarin 2, which through a Williamson reaction with 2-chlorocyclopentanone gave the oxoether $\mathbf{3}$ in $90 \%$ yield. Cyclization of $\mathbf{3}$ in strongly alkaline solution afforded the ciclopentenefurocoumarin 4 in 30\% yield.

The pyrone side derivative 9 was obtained by the treatment of the hydroxycoumarin 5 with 2,3-dibromopropene, and following cyclization of the achieved product 8 in $40 \%$ overall yield.

Compound 20 was synthesised from hydroxycoumarin 13 in a 4-step reaction: the reaction of the latter with 2,3-dibromopropene, in the same manner as $\mathbf{8}$ from $\mathbf{5}$, gave the resulting ether 17 which then was oxidized with DDQ in toluene to give 19 in $62 \%$ overall yield. Finally, the cyclization of 19 with N,N-diethylaniline produced the benzoderivative $\mathbf{2 0}$ in $52 \%$ yield.

Compound 18 was also prepared through a different synthetic route with respect to that already described ${ }^{22}$ starting from 17 by reaction with the $N, N$-diethylaniline as base, in $57 \%$ yield.

\section{Photobiological activity}

The antiproliferative activity of the new methyl derivatives, cyclopentene- (4, 7 and 9) tetrahydrobenzo- (11, 15 and 18) and benzo-psoralens $(\mathbf{1 2}, 16$ and 20) was evaluated on HeLa and HL-60 human tumor cell lines. The photochemotherapeutic drug 8-MOP was taken into account as reference compound. The results obtained after exposure to UVA light $\left(0.793 \mathrm{~J} \mathrm{~cm}^{-2}\right.$ at $365 \mathrm{~nm}$ ) are reported in Table 1 and expressed as $\mathrm{IC}_{50}$ values, i.e. the concentration of compound $(\mu \mathrm{M})$ able to induce $50 \%$ cell death with respect to the control culture.

Table 1. Cell growth inhibition and skin phototoxicity in guinea pigs in the presence of examined compounds and 8-MOP as reference drug

\begin{tabular}{|c|c|c|c|c|}
\hline \multirow[b]{2}{*}{ Compd } & \multicolumn{2}{|c|}{$\mathrm{IC}_{50}(\mu \mathrm{M})$ of cell lines } & \multicolumn{2}{|c|}{ Skin phototoxicity } \\
\hline & $\mathrm{HeLa}$ & HL-60 & $\begin{array}{c}\text { dose } \\
\left(\mathrm{mmol} / \mathrm{cm}^{2}\right)\end{array}$ & $\begin{array}{l}\text { erythema } \\
\text { intensity }^{\mathrm{a}}\end{array}$ \\
\hline 4 & $0.65 \pm 0.15$ & $2.4 \pm 0.4$ & 0.08 & ++- \\
\hline 7 & $1.05 \pm 0.26$ & $3.3 \pm 0.6$ & 0.08 & ++ \\
\hline 9 & $0.66 \pm 0.16$ & $2.8 \pm 0.6$ & 0.08 & ++- \\
\hline 11 & $0.59 \pm 0.13$ & $1.7 \pm 0.2$ & 0.08 & +-- \\
\hline 15 & $0.45 \pm 0.05$ & $2.7 \pm 0.3$ & 0.08 & - - - \\
\hline 18 & $0.65 \pm 0.07$ & $4.3 \pm 0.4$ & 0.08 & $+\ldots$ \\
\hline 12 & $0.63 \pm 0.06$ & $1.8 \pm 0.2$ & 0.19 & $-\ldots$ \\
\hline 16 & $0.47 \pm 0.07$ & $2.0 \pm 0.2$ & 0.19 & -- \\
\hline 20 & $0.65 \pm 0.07$ & $1.4 \pm 0.1$ & 0.19 & $\ldots$ \\
\hline $8-\mathrm{MOP}^{\mathrm{b}}$ & $10 \pm 3$ & $5.4 \pm 0.7$ & 0.05 & +++ \\
\hline
\end{tabular}


All the methyl derivatives are able to exert a noticeable antiproliferative activity towards both tumor cell lines. In detail, in the HeLa cells the $\mathrm{IC}_{50}$ values of the new compounds appear to be from 8 to 22 times lower with respect to that calculated for 8-MOP. As regards the human promyelocytic leukemia cell line, HL-60, it appears to be less sensitive toward the treatment with the new compounds. Indeed, the $\mathrm{IC}_{50}$ values are only slightly lower in comparison with that of the reference drug. It is interesting to note that, notwithstanding the remarkable antiproliferative activity exerted upon treatment with UVA light, none of the considered compounds show cytotoxic effect in the dark (data not shown).

Comparing the above results with the chemical molecular structure of the tetracyclic methyl derivatives, it is evident that the extension of the tricyclic psoralen moiety, due to the condensation of a fourth ring, appears to be always relevant to increase the photoantiproliferative activity. Nevertheless, the ability to inhibit cell growth seems not to be correlated with the chemical structure of the fourth ring. In particular, both the steric hindrance caused by lack of aromaticity in the hydrogenated rings (cyclohexane for 11, 15 and 18, cyclopentane for 4, 7 and 9) and the delocalization of the electron density due to a tetracyclic aromatic system (12, 16 and 20) similarly affect the antiproliferative ability of the psoralen chromophore. An analogous consideration has to be made with regards to the role played by the methyl substituents. Indeed, it seems that their position (4, 4' or 5' of the psoralen moiety) do not constitute a critical factor for the cytotoxicity. In detail, it could be stated that the presence of a methyl substituent both at the pyrone side double bond and at the furan side double bond does not compromise the capacity of these site to exert their photoreactivity.

The induction of skin phototoxicity, determined by evaluating the appearance of erythema, a marker of cutaneous sensitization, was investigated and the results obtained are shown in Table 1. It can be noted that, unlike in the case of the antiproliferative activity, the chemical structure of the fourth condensed ring is crucial in determining the appearance of this undesired side effect. In particular, the benzopsoralen derivatives 12, 16 and 20 appear to be devoid of photosensitizing effect, even if they are applied on skin at a concentration 3.8 times higher with respect to that of the reference drug. As regards the derivatives characterized by the condensation of a cyclohexenyl ring it is noteworthy that the presence of the fourth ring at the pyrone side of the tricyclic psoralen moiety, along with the presence of a methyl substituent at 4' position of the furan side (compound 15), constitutes the most interesting tetrahydrobenzopsoralen structure, since it does not induce skin phototoxicity. By contrast, with analogues $\mathbf{1 1}$ and $\mathbf{1 8}$ the appearance of a certain skin photosensitization was scored, even though it is significantly lower if compared with the effect induced by 8-MOP. Finally, the compounds 4, 7 and $\mathbf{9}$, characterized by the condensation of a cyclopentene ring at pyrone or furan side, induce skin phototoxicity. Nevertheless, it has to be underlined that also in this case the undesired side effect is diminished with respect to that exerted by the reference drug. 


\section{Photobinding to DNA}

It is well known that in the ground state the psoralen tryciclic moiety forms a preliminary complex with DNA in which the planar chromophore undergoes intercalation inside two base pairs. ${ }^{23}$ After UVA irradiation, the intercalated ligand photobinds covalently to DNA giving rise to monoadducts and diadducts.

Similar behavior was also already observed for various tetracyclic psoralen derivatives carrying both a benzene $e^{10,11,14,15}$ or a cyclohexane ${ }^{11,14,15}$ as fourth ring. In detail, in these previous studies the ability of benzopsoralen and tetrahydrobenzopsoralen derivatives to photobind to DNA bases was widely demonstrated by the evaluation of the amount of radiolabelled compounds photoadded to the macromolecule $\mathrm{e}^{10,11,14}$ and by the isolation and characterization of the monoadducts. ${ }^{15}$ In particular, it was clearly shown that the condensation of a cyclohexenyl or benzenic ring to a photoreactive double bond affects its photoaddition ability towards the DNA bases in a very different way. In detail, the steric hindrance caused by lack of aromaticity in the hydrogenated ring does not prevent the ability to photoaddition, while the delocalization of the electron density of the photoreactive double bond of the furocoumarin moiety in a tetracyclic aromatic system impedes its involvement in the cycloaddition. ${ }^{11,14,15}$

In this connection, the investigation was also undertaken into the photoaddition process of the methyl tetrahydrobenzo and benzopsoralen derivatives. In detail, the irradiation (365 $\mathrm{nm})$ of an aqueous solution of DNA in the presence of the considered compounds, followed by precipitation and acid hydrolysis, as described in the Experimental Section, allowed us to isolate a photoproduct characterized by a strong violet fluorescence upon exposure to $365 \mathrm{~nm}$ UV light. This characteristic is typical of furocoumarins having a 3,4-ethylenic bond within the pyrone ring and thus is usually retained consistent with the molecular structure of the furan side monoadduct. ${ }^{24}$ Furthermore, the UV absorption spectra of an ethanol solution of the isolated fluorescent products showed the disappearance of the peculiar furocoumarin band around 300 $\mathrm{nm}$ and an evident absorption at $330 \mathrm{~nm}$ which gradually disappears as the irradiation time is increased to $254 \mathrm{~nm}$ (spectra not shown). This behavior further confirms the above assumption; indeed it was already established that the $\mathrm{C}_{4}$-cycloadducts undergo breakage upon $254 \mathrm{~nm}$ irradiation, yielding the parent compounds, i.e. the psoralen and the DNA base.

As already demonstrated for psoralens and also for benzo and tetrahydrobenzopsoralen derivatives, ${ }^{14,15}$ inside DNA bases, thymine constitutes by far the preferred target of the photoreaction. The mass spectra of the photoproduct of the tetrahydrobenzopsoralen 11, where the major peak appears at $\mathrm{m} / \mathrm{z}=395$, and of the benzopsoralen 16 which shows the major peak at $\mathrm{m} / \mathrm{z}=391$, are consistent with a thymine-11 and a thymine-16 photoadduct, respectively (spectra not shown).

As regards the cyclopentene-psoralen tetracyclic moiety, a previous study reports some indications on its ability to photobind covalently to DNA. ${ }^{16}$ In this connection, it appeared of interest to investigate the ability of 4,7 and 9 to photoadd to the macromolecule. In detail, the capacity of the methyl cyclopentenepsoralen derivatives to give rise to a covalent photoadduct 
with DNA bases was demonstrated by the isolation and characterization of the furan side monoadduct obtained after UVA irradiation of an aqueous solution of DNA and the above compounds as described in the Experimental Section. After TLC separation a fluorescent band appears. The UV spectrum of an ethanol solution of this photoproduct shows the typical characteristics of the $\mathrm{C}_{4}$-cycloadducts between the furan double bond of the furocoumarin and the 5,6 double bond of a pyrimidine base, i.e. an evident absorption at $330 \mathrm{~nm}$ and the disappearance of the peculiar furocoumarin band around $300 \mathrm{~nm}$, present in the spectrum of 4, 7 and 9. Photoreversion experiments provide further evidence on the photoadduct formation. In Figure 1, the UV absorption spectra of the photoproduct, obtained by the photoreaction between 4 and DNA, before (line a) and after increasing periods of irradiation at $254 \mathrm{~nm}$ (lines b-f), is shown as an example.

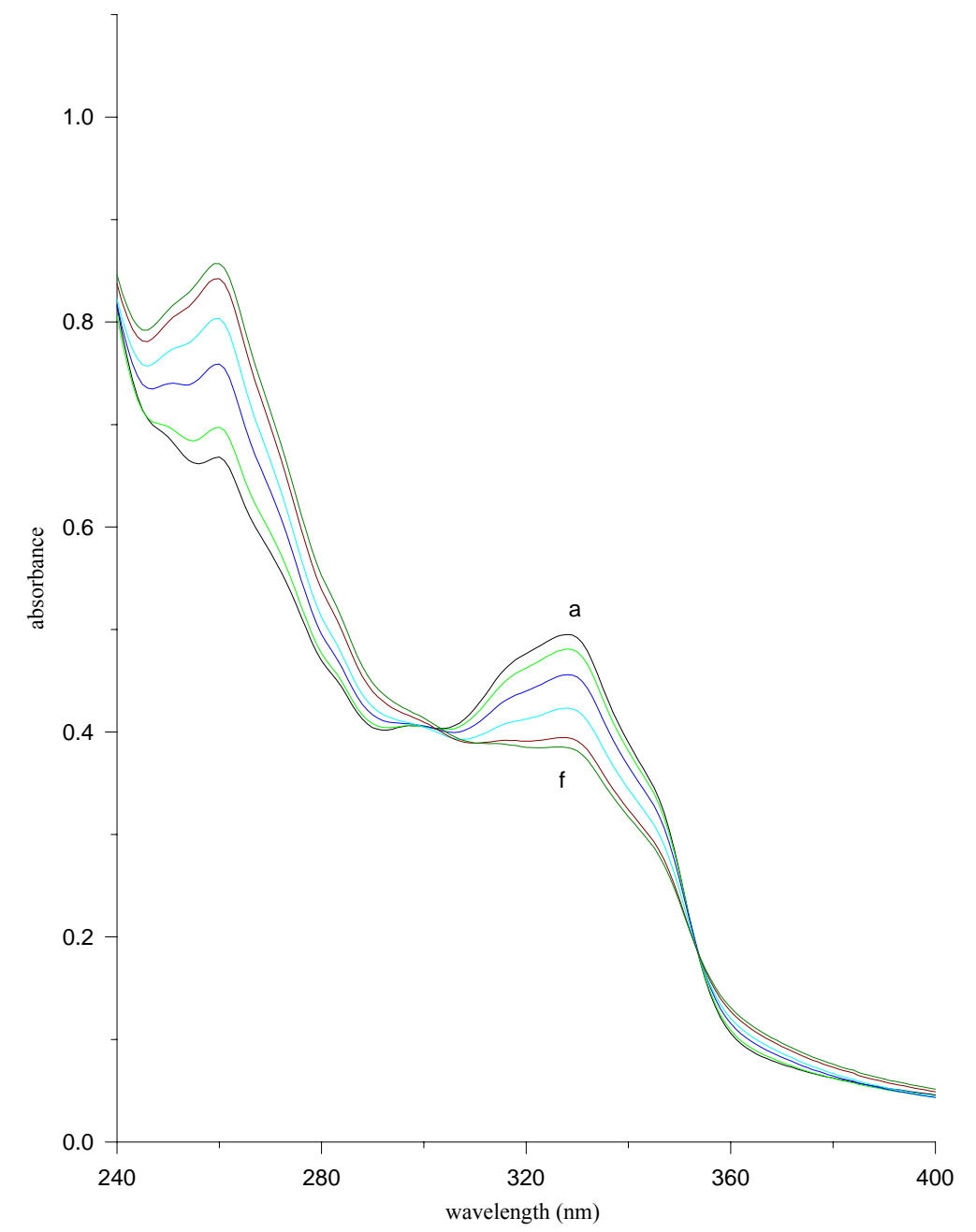

Figure 1. UV absorption spectra of an ethanol solution of furan cycloadduct obtained from DNA and 4 before (line a) and after irradiation at $254 \mathrm{~nm}(10,30,60,120,180 \mathrm{~min}$, lines b-f, respectively). 
The analysis of the fluorescent photoproducts by mass spectrometry confirms also for cyclopentenepsoralen derivatives $\mathbf{4}, 7$ and 9 the preference to covalent photoadd to pyrimidine bases, and in particular to thymine. Indeed, the mass spectra show the presence of a major peak at $m / z=381$ which is consistent with a thymine-cyclopentenepsoralen cycloadduct (spectra not shown).

In particular, the results obtained allow us to affirm that, similarly to what was demonstrated for the tetrahydrobenzosporalen moiety, the cyclopentane ring fused at a photoreactive double bond did not seem to compromise its DNA photoaddition capacity.

\section{Cross-linking}

The furan side monoadduct possesses the important property to absorb at $365 \mathrm{~nm}$. This ability allows the formation of interstrand cross-links. As already stated, the condensation of the aromatic fourth ring renders the tetracyclic benzopsoralens monofunctional molecules, indeed both 16 and 20 are unable to form interstrand cross-links (data not shown). Regarding the tetrahydrobenzopsoralen derivatives 11, 15 and 18, Figure 2a shows the results obtained by denaturation-renaturation experiments, in comparison with 8-MOP.

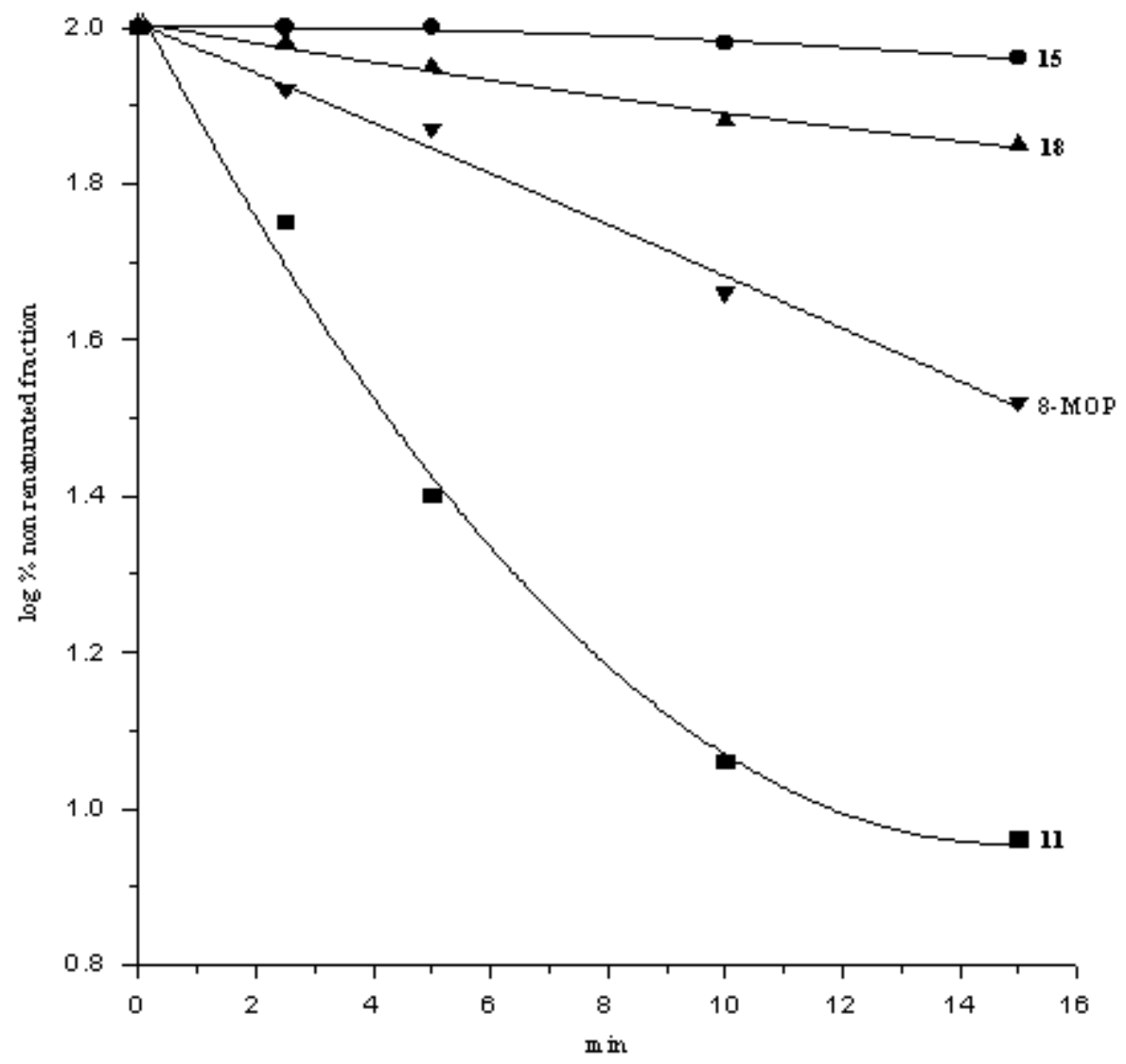

Figure 2a. Cross-linking of compounds 11, 15, 18 and 8-MOP to double stranded DNA (nucleotide/drug=75) as a function of irradiation time. 
From the behaviors shown in Figure 2a it can be noted that a noticeable difference appears between the ability to induce cross-links exerted by 15 and 18 with respect to that of 11 . In particular, the two tetrahydrobenzopsoralens characterized by the condensation of the fourth ring to the pyrone side of the psoralen chromophore (compounds 15 and 18) show a negligible capacity to induce cross-links. Also, the derivative carrying the fourth condensed ring at the 4',5' furan side double bond (compound 11) is able to exert a much higher capacity, even considerably higher in comparison with that induced by the reference drug 8-MOP. These overall results appear to be in agreement with previous studies where the ability to induce cross-links of furan side $^{14}$ and pyrone side ${ }^{15}$ tetrahydrobenzopsoralens was evaluated.

Denaturation-renaturation experiments was performed also for cyclopentenepsoralen derivatives 4, 7 and 9. The results shown in Figure $2 \mathrm{~b}$ indicate for these compounds a remarkable ability to give rise to cross-links with double stranded DNA. Indeed, in the presence of both 4, 7 and $\mathbf{9}$, the double helix shows a renaturation capacity higher with respect to that induced by 8 MOP.

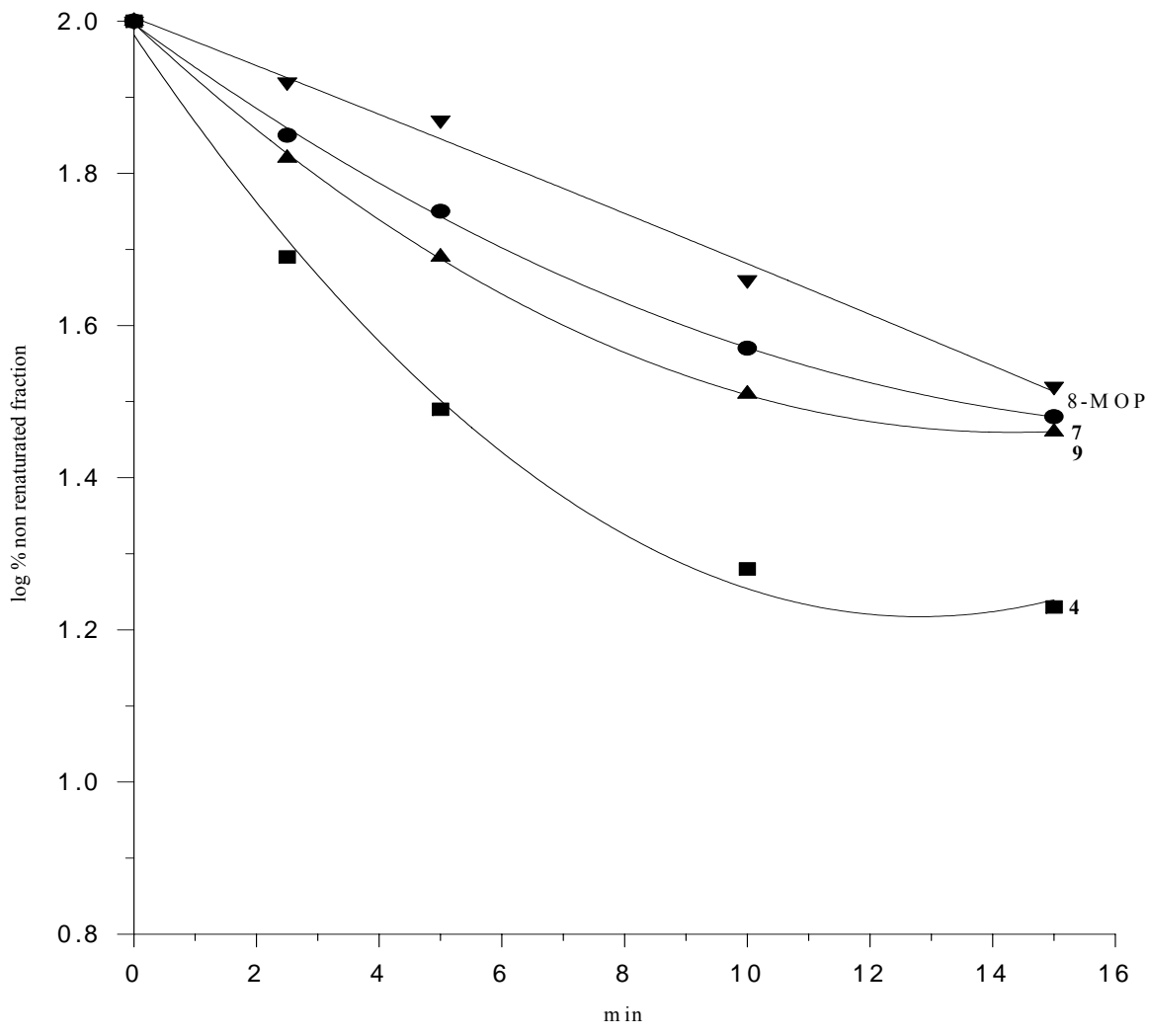

Figure 2b. Cross-linking of compounds 4, 7, 9 and 8-MOP to double stranded DNA (nucleotide/drug=75) as a function of irradiation time.

Furthermore, similarly to tetrahydrobenzopsoralens 11, 15 and 18, also for the cyclopentene derivatives this capacity appears dependent from the position of the fourth ring. In detail, 
compound 4, characterized by the condensation of the cyclopentane at the level of furan side, is able to induce cross-links more efficiently with respect to the congeners carrying the cyclopentane ring condensed at the 4',5' double bond (7 and 9).

Taken together, this results seem to indicate that the steric hyndrance, due to the presence of a saturated ring at the level of 3,4 photoreactive double bond of the furan side monoadduct, hindered the subsequent monoaddition. On the contrary, once the furan side monoadduct takes place, the presence of a fourth ring at the 4',5' level probably does not affect significantly the subsequent photoaddition involving the 3,4 pyrone side.

Comparing the above data with those reported in Table 1, it is possible to conclude that, notwithstanding the fact that cross-links undoubtedly constitute lethal damage for the cell, there is not a linear relationship between the capacity to give rise to this molecular event and the ability to induce cell death. Consequently, it is reasonable to assume that they are not the leading molecular consequence accountable for the cellular cytotoxicity derived from UVA treatment in the presence of these derivatives.

Similarly, despite a previous hypothesis of a correlation between furocoumarin capacity for crosslinking DNA and skin phototoxicity, ${ }^{25}$ the obtained results (see Fig. $2 \mathrm{a}$ and $2 \mathrm{~b}$ and Table 1) appear in conflict with this assumption and indicate, rather, the existence of complex mechanism(s) responsible for this undesired side effect.

\section{Conclusions}

The photobiological behaviour of cyclopentene- $(4,7$ and 9), tetrahydrobenzo- (11, 15 and 18$)$ and benzo-psoralens (12, 16 and 20), carrying two methyl groups in different positions of the psoralen cromophore, was investigated. In particular, for all the tested compounds a noticeable and comparable photoantiproliferative activity was scored. Interestingly, in HeLa cells they appears to exert an antiproliferative activity from 8 to 22 times greater with respect to that of 8 MOP. On the other hand, evaluation of skin phototoxicity brought out significant differences depending on the type of the fourth ring condensed to the psoralen moiety. In particular, the following order in inducing skin photosensitisation is detected: 8-MOP $>$ cyclopentenepsoralens $>$ tetrahydrobenzo-psoralens $>$ benzo-psoralens. In this connection, it is noteworthy that in our experimental conditions the derivatives 12, 16 and 20 appear unable to induce the appearance of any erythema, even when tested at a concentration higher than that of 8-MOP.

As regards the ability to interact with DNA, the tetracyclic derivatives seem to act like the parent compound. The capacity to photoreact with the macromolecule was demonstrated, and in particular, a preference toward the pyrimidine base thymine was highlighted. As regards the capacity to behave as bifunctional molecules, both tetrahydrobenzopsoralens and cyclopentenepsoralens are able to induce interstrand cross-links. Nevertheless, the capacity to photoreact with the opposite DNA strands appears strongly dependent on the photoreactive side at which the condensation of the fourth ring occurs. In detail, condensation at the level of the 
pyrone double bond strongly prevents the formation of cross-links as compared with condensation on the furan side. Furthermore, it can be underlined that this inhibitory effect is more pronounced for tetrahydrobenzopsoralens than for cyclopentenepsoralens and it could be attributable to the wider steric hindrance of the cyclohexane, so that it could influence more strongly the correct superimposition of the photoreactive double bonds during the bifunctional photoaddition.

In conclusion, the study of the photobiological behavior of structurally correlated tetracyclic psoralen derivatives allowed us to highlight some relationships between molecular events and structural properties and this knowledge could constitute a preliminary goal in the rational planning of new more promising photochemotherapeutic agents.

\section{Experimental Section}

General Procedures. Melting points are uncorrected and were determined in a Reichert Kofler thermopan or in capillary tubes in a Büchi 510 apparatus. IR spectra were recorded in a PerkinElmer 1640FT spectrometer ( $\mathrm{KBr}$ disks, $v$ in $\left.\mathrm{cm}^{-1}\right) .{ }^{1} \mathrm{H}-\mathrm{NMR}(300 \mathrm{MHz})$ and ${ }^{13} \mathrm{C}-\mathrm{NMR}(75.4$ $\mathrm{MHz}$ ) spectra were recorded in a Bruker AMX spectrometer, using TMS as internal standard (chemical shifts in $\delta$ values, $J$ in Hz). Mass spectrometry was carried out on a Kratos MS-50 or on a Varian AT-711 spectrometer. Elemental analyses were performed by a Perkin-Elmer 240B microanalyser and were within $\pm 0.4 \%$ of calculated values in all cases. Flash chromatography (FC) was performed on silica gel (Merck 60, 230-400 mesh); analytical TLC was performed on precoated silica gel plates (Merck 60 F254, $0.25 \mathrm{~mm}$ ).

4,8-Dimethyl-7-(2'-oxocyclopentyloxy)coumarin (3). To a solution of $2(500 \mathrm{mg}, 2.62 \mathrm{mmol})^{26}$ in dry acetone $(30 \mathrm{~mL})$ were added 2-chlorocyclopentanone $(525 \mu \mathrm{L}, 623 \mathrm{mg}, 5.25 \mathrm{mmol})$ and $\mathrm{K}_{2} \mathrm{CO}_{3}$ (726 mg, $5.25 \mathrm{mmol}$ ), and the reaction mixture was refluxed for $24 \mathrm{~h}$. The precipitate was filtered out and the solvent concentrated under reduced pressure. The crude product was purified by FC using hexane/ethyl acetate (3:1) as eluent, yielding pure 3 (644 mg, 90.1\%). $\mathrm{Mp} 187^{\circ} \mathrm{C}$. IR: 2922, 1722, 1605, 1288, 1119. ${ }^{1} \mathrm{H}$ NMR $\left(\mathrm{CDCl}_{3}\right): 2.09$ (m, 2H + 2H, H-4' + H-5'), 2.31 (s, 3H, Me-C8), 2.39 (d, $J=1.1 \mathrm{~Hz}, 3 \mathrm{H}, \mathrm{Me}-\mathrm{C} 4), 2.47$ (m, 2H, H-3'), 4.70 (t, $J=7.8 \mathrm{~Hz}, 1 \mathrm{H}, \mathrm{H}-1^{\prime}$ ), 6.14 (d, $J=1.1 \mathrm{~Hz}, 1 \mathrm{H}, \mathrm{H}-3), 6.94$ (d, $J=8.8 \mathrm{~Hz}, 1 \mathrm{H}, \mathrm{H}-6), 7.39$ (d, $J=8.8 \mathrm{~Hz}, 1 \mathrm{H}, \mathrm{H}-5) .{ }^{13} \mathrm{C}$

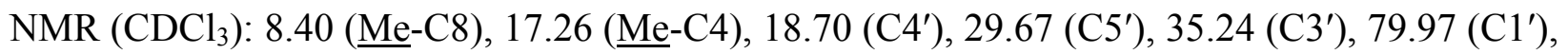
109.52 (C3), 112.12 (C6), 114.35 (C8), 115.15, 122.28 (C5), 152.64, 152.74, 158.69, 161.52 (C2), $213.41\left(\mathrm{C} 2^{\prime}\right)$. MS m/z (\%): 273([M+1 $\left.]^{+}, 16\right), 272\left(\mathrm{M}^{+}, 92\right), 201(32), 190(90), 162(100)$, 115(26). Anal. $\mathrm{C}_{16} \mathrm{H}_{16} \mathrm{O}_{4}: \mathrm{C}, \mathrm{H}$.

4',5'-Cyclopentene-4,8-dimethylfuro[3,2-g]coumarin (4). A mixture of 3 (510 mg, $1.87 \mathrm{mmol}$ ) and $1 \mathrm{M} \mathrm{NaOH}(30 \mathrm{~mL})$ was refluxed for $24 \mathrm{~h}$, cooled, and acidified with $3 \mathrm{M} \mathrm{HCl}$. The precipitate was recovered by filtration and washed with water. The crude product was purified by FC using hexane/ethyl acetate (19:1) as eluent, yielding pure 4 (143 mg, 30\%). Mp $153^{\circ} \mathrm{C}$. IR: 
2922, 2850, 1706, 1558, 1480, 1396, 1125, 1092. ${ }^{1} \mathrm{H}$ NMR $\left(\mathrm{CDCl}_{3}\right): 2.48$ (s, 3H, Me-C8), 2.57 (s, $3 \mathrm{H}, \mathrm{Me}-\mathrm{C} 4), 2.59$ (m, 2H, $\mathrm{CH}_{2} \mathrm{C}_{2} \mathrm{CH}_{2}$ ), 2.78 (m, 2H, $\left.\underline{\mathrm{C}}_{2}-\mathrm{C} 5^{\prime}\right), 2.90$ (m, 2H, $\mathrm{C}_{2}-\mathrm{C} 4$ '), 6.24 (s, $1 \mathrm{H}, \mathrm{H}-3), 7.41$ (s, $1 \mathrm{H}, \mathrm{H}-5) .{ }^{13} \mathrm{C}$ NMR $\left(\mathrm{CDCl}_{3}\right): 8.9$ (Me-C8), 19.7 (Me-C4), 23.1 $\left(\mathrm{CH}_{2} \mathrm{CH}_{2} \mathrm{CH}_{2}\right), 25.6\left(\underline{\mathrm{CH}}_{2}-\mathrm{C}^{\prime}\right), 27.6\left(\underline{\mathrm{CH}}_{2}-\mathrm{C}^{\prime}\right), 110.6$ (C8), 111.3 (C3), 113.2 (C5), 116.2, 121.7, 123.3, 148.9, 153.8, 161.4, 162.1, 164.9 (C2). MS m/z (\%): 254(M $\left.\mathrm{M}^{+}, 80\right), 226\left(\mathrm{M}^{+}-\mathrm{CO}\right.$, 100), 225(98), 199(18), 183(15), 149(56). Anal. $\mathrm{C}_{16} \mathrm{H}_{14} \mathrm{O}_{3}: \mathrm{C}, \mathrm{H}$.

7-( $\beta$-Bromoallyloxy)-3,4-cyclopentene-8-methylcoumarin (8). This compound was prepared from $5(1.0 \mathrm{~g}, 4.62 \mathrm{mmol})^{2}, \mathrm{~K}_{2} \mathrm{CO}_{3}(958 \mathrm{mg}, 6.93 \mathrm{mmol})$ and 2,3-dibromopropene $(716 \mu \mathrm{L}, 1.38$ $\mathrm{g}, 6.93 \mathrm{mmol}$ ) in the same way as $\mathbf{3}$. The crude product was purified by FC using hexane/ethyl acetate (6:1) as eluent, yielding pure $8(1.2 \mathrm{~g}, 77.7 \%)$. Mp $140^{\circ} \mathrm{C}$. IR: $2919,1716,1611,1373$, 1282, 1109, 803. ${ }^{1} \mathrm{H}$ NMR $\left(\mathrm{CDCl}_{3}\right): 2.19$ (m, 2H, $\mathrm{CH}_{2} \mathrm{CH}_{2} \mathrm{CH}_{2}$ ), 2.38 (s, 3H, Me-C8), 2.90 (t, $J$ $\left.=7.5 \mathrm{~Hz}, 2 \mathrm{H}, \mathrm{CH}_{2}-\mathrm{C} 4\right), 3.03\left(\mathrm{t}, J=7.6 \mathrm{~Hz}, 2 \mathrm{H}, \mathrm{CH}_{2}-\mathrm{C} 3\right), 4.72\left(\mathrm{~s}, 2 \mathrm{H}, \mathrm{CH}_{2} \mathrm{O}\right), 5.71(\mathrm{~d}, J=$ $2.1 \mathrm{~Hz}, 1 \mathrm{H}, \mathrm{C}=\mathrm{CH}), 6.01(\mathrm{~d}, J=2.1 \mathrm{~Hz}, 1 \mathrm{H}, \mathrm{C}=\mathrm{CH}), 6.77(\mathrm{~d}, J=8.6 \mathrm{~Hz}, 1 \mathrm{H}, \mathrm{H}-6), 7.23(\mathrm{~d}, J=$ $8.6 \mathrm{~Hz}, 1 \mathrm{H}, \mathrm{H}-5) .{ }^{13} \mathrm{C} \mathrm{NMR}\left(\mathrm{CDCl}_{3}\right): 8.61(\mathrm{Me}-\mathrm{C} 8), 22.56\left(\mathrm{CH}_{2} \mathrm{CH}_{2} \mathrm{CH}_{2}\right), 30.40\left(\underline{\mathrm{CH}}_{2}-\mathrm{C} 4\right)$, $32.07\left(\underline{\mathrm{CH}}_{2}-\mathrm{C} 3\right), 72.02\left(\mathrm{CH}_{2} \mathrm{O}\right), 108.09$ (C6), $113.26(\mathrm{C} 8), 114.81,118.00\left(\underline{\mathrm{CH}}_{2}=\mathrm{C}\right), 122.47$ (C5), 124.94, 126.52, 153.40, 156.40, 157.63, 160.58 (C2). MS m/z (\%): 336([M+2] $\left.]^{+}, 12\right)$, 335( $\left.\mathrm{M}^{+}, 12\right), 255(76), 215(29), 187(100), 128(15)$. Anal. $\mathrm{C}_{16} \mathrm{H}_{15} \mathrm{BrO}_{3}: \mathrm{C}, \mathrm{H}$.

3,4-Cyclopentene-5',8-dimethylfuro[3,2-g]coumarin (9). A solution of 8 (218 mg, $0.65 \mathrm{mmol})$ in N,N-diethylaniline $(5 \mathrm{~mL})$ was refluxed for $40 \mathrm{~h}$. The solution was cooled, and ethyl ether was added $(35 \mathrm{~mL})$. The precipitate was filtered, washed with $1 \mathrm{~N} \mathrm{NaOH}(3 \times 25 \mathrm{~mL})$ and $6 \mathrm{~N} \mathrm{HCl}(2$ x $25 \mathrm{~mL})$, the extract was dried $\left(\mathrm{Na}_{2} \mathrm{SO}_{4}\right)$, and the solvent was evaporated under reduced pressure. The crude product was purified by FC using hexane/ethyl acetate $(6: 1)$ as eluent, yielding pure 9 ( $85 \mathrm{mg}, 52.0 \%)$. Mp $213^{\circ} \mathrm{C}$. IR: $3068,2923,1716,1593,1173,1101,807 .{ }^{1} \mathrm{H}$ $\operatorname{NMR}\left(\mathrm{CDCl}_{3}\right): 2.20\left(\mathrm{~m}, 2 \mathrm{H}, \mathrm{CH}_{2} \mathrm{CH}_{2} \mathrm{CH}_{2}\right), 2.48\left(\mathrm{~d}, \mathrm{~J}=1.0 \mathrm{~Hz}, 3 \mathrm{H}, \mathrm{Me}-\mathrm{C5}^{\prime}\right), 2.56$ (s, 3H, MeC8), $2.91\left(\mathrm{t}, \mathrm{J}=7.5 \mathrm{~Hz}, 2 \mathrm{H}, \mathrm{CH}_{2}-\mathrm{C} 4\right), 3.08\left(\mathrm{t}, \mathrm{J}=7.6 \mathrm{~Hz}, 2 \mathrm{H}, \mathrm{CH}_{2}-\mathrm{C} 3\right), 6.37$ (d, J = 1.0Hz, $1 \mathrm{H}$, $\left.\mathrm{H}-4{ }^{\prime}\right), 7.28$ (s, $\left.1 \mathrm{H}, \quad \mathrm{H}-5\right) .{ }^{13} \mathrm{C}$ NMR $\left(\mathrm{CDCl}_{3}\right): 8.69$ (Me-C8), 14.20 (Me-C5'), 22.44 $\left(\mathrm{CH}_{2} \mathrm{CH}_{2} \mathrm{CH}_{2}\right), 30.54\left(\underline{\mathrm{CH}}_{2}-\mathrm{C} 4\right), 32.40\left(\underline{\mathrm{CH}}_{2}-\mathrm{C} 3\right), 102.50\left(\mathrm{C}^{\prime}\right), 108.92$ (C8), 112.09 (C5), 114.77, 124.96, 125.25, 149.41, 154.93, 156.98, 157.12, 160.79 (C2). MS m/z (\%): 255([M+1] $]^{+}$, 17), 254(M+1 97), 226(100), 199(48), 183(26), 153(12). Anal. $\mathrm{C}_{16} \mathrm{H}_{14} \mathrm{O}_{3}: \mathrm{C}, \mathrm{H}$.

7-( $\beta$-Bromoallyloxy)-3,4-cyclohexene-8-methylcoumarin (17). This compound was prepared from $13(1.1 \mathrm{~g}, 4.8 \mathrm{mmol})^{3}, \mathrm{~K}_{2} \mathrm{CO}_{3}(1.0 \mathrm{~g}, 7.2 \mathrm{mmol})$ and 2,3-dibromopropene $(747 \mu \mathrm{L}, 1.4 \mathrm{~g}$, $7.2 \mathrm{mmol}$ ) in the same way as 3 . The crude product was purified by FC using hexane/ethyl acetate (6:1) as eluent, yielding pure $17(1.27 \mathrm{~g}, 75.9 \%)$. Mp: $135-136^{\circ} \mathrm{C}$. IR: $3071,2935,1708$, 1605, 1114, 755. ${ }^{1} \mathrm{H}$ NMR $\left(\mathrm{CDCl}_{3}\right): 1.82\left(\mathrm{~m}, 4 \mathrm{H}, \mathrm{CH}_{2}\left(\mathrm{CH}_{2}\right)_{2} \mathrm{CH}_{2}\right), 2.35$ (s, 3H, Me-C8), 2.56 (m, $\left.2 \mathrm{H}, \mathrm{CH}_{2}-\mathrm{C} 4\right), 2.72\left(\mathrm{~m}, 2 \mathrm{H}, \mathrm{CH}_{2}-\mathrm{C} 3\right), 4.71\left(\mathrm{~s}, 2 \mathrm{H}, \mathrm{CH}_{2} \mathrm{O}\right), 5.76(\mathrm{~d}, J=1.6 \mathrm{~Hz}, 1 \mathrm{H}, \mathrm{C}=\mathrm{CH}), 6.01$ $(\mathrm{d}, J=1.6 \mathrm{~Hz}, 1 \mathrm{H}, \mathrm{C}=\mathrm{CH}), 6.75(\mathrm{~d}, J=8.8 \mathrm{~Hz}, 1 \mathrm{H}, \mathrm{H}-6), 7.35(\mathrm{~d}, J=8.8 \mathrm{~Hz}, 1 \mathrm{H}, \mathrm{H}-5) .{ }^{13} \mathrm{C}$ NMR $\left(\mathrm{CDCl}_{3}\right): 8.78$ (e- $\left.-\mathrm{C} 8\right), 21.86\left(\underline{\mathrm{CH}}_{2}-\mathrm{CH}_{2} \mathrm{C} 3\right), 22.11\left(\underline{\mathrm{CH}}_{2}-\mathrm{CH}_{2} \mathrm{C} 4\right), 24.31\left(\underline{\mathrm{C}} \mathrm{H}_{2}-\mathrm{C} 3\right), 25.65$ $\left(\underline{\mathrm{CH}}_{2}-\mathrm{C} 4\right), 72.36\left(\underline{\mathrm{CH}}_{2} \mathrm{O}\right), 108.32(\mathrm{C} 6), 114.80(\mathrm{C} 8), 115.04,118.36\left(\underline{\mathrm{CH}}_{2}=\mathrm{C}\right), 121.26,121.35$ (C5), 127.03, 147.64, 151.57, 157.47, 162.60 (C2). MS m/z (\%): 350 ([M+2] $\left.]^{+}, 4\right), 349\left(\mathrm{M}^{+}, 22\right)$, 269 (89), 229 (100), 201 (58), 187 (40). Anal. $\mathrm{C}_{17} \mathrm{H}_{17} \mathrm{BrO}_{3}$ : C, 58.44; H, 4.87. 
3,4-Cyclohexene-5',8-dimethylfuro[3,2-g]coumarin (18). This compound was prepared from $17(2.5 \mathrm{~g}, 7.1 \mathrm{mmol})$ and $N, N$-diethylaniline $(55 \mathrm{~mL})$, in the same way as $\mathbf{9}$ from $\mathbf{8}$. The residue was purified by FC using hexane/ethyl acetate (6:1) as eluent, yielding $\mathbf{1 8}(1.1 \mathrm{~g}, 57.1 \%)$.

3,4-Benzo-7-( $\beta$-bromoallyloxy)-8-methylcoumarin (19). A solution of 17 (106 mg, $0.30 \mathrm{mmol})$ and DDQ (137 mg, $0.60 \mathrm{mmol})$ in toluene $(15 \mathrm{~mL})$ was refluxed for $5 \mathrm{~h}$. The mixture was cooled, the precipitate collected, the solvent evaporated under reduced pressure, and the resulting residue purified by $\mathrm{FC}$ using $\mathrm{CHCl}_{3}$ as eluent, giving pure 19 (85 mg, 81.7\%). Mp: $128^{\circ} \mathrm{C}$. IR: 2921, 1726, 1608, 1470, 1283, 1115, 891, 766. ${ }^{1} \mathrm{H}$ NMR $\left(\mathrm{CDCl}_{3}\right): 2.38$ (s, 3H, Me-C8), 4.72 (s, $\left.2 \mathrm{H}, \mathrm{CH}_{2} \mathrm{O}\right), 5.72(\mathrm{~d}, J=1.9 \mathrm{~Hz}, 1 \mathrm{H}, \mathrm{C}=\mathrm{CH}), 6.03(\mathrm{~d}, J=1.9 \mathrm{~Hz}, 1 \mathrm{H}, \mathrm{C}=\mathrm{CH}), 6.80(\mathrm{~d}, J=$ $8.8 \mathrm{~Hz}, 1 \mathrm{H}, \mathrm{H}-6), 7.49$ (m, 1H, C$-\mathrm{CHC} 4), 7.78(\mathrm{~m}, 1 \mathrm{H}+1 \mathrm{H}, \mathrm{C} \underline{\mathrm{H}}-\mathrm{CHC} 3+\mathrm{H}-5), 7.98(\mathrm{~d}, J=$ $8.0 \mathrm{~Hz}, 1 \mathrm{H}, \mathrm{CH}-\mathrm{C} 3), 8.34$ (d, $J=8.0 \mathrm{~Hz}, 1 \mathrm{H}, \mathrm{CH}-\mathrm{C} 4) .{ }^{13} \mathrm{C} \mathrm{NMR}\left(\mathrm{CDCl}_{3}\right): 8.95$ ( $\left.\mathrm{Me}-\mathrm{C} 8\right), 72.33$ $\left(\underline{\mathrm{CH}}_{2} \mathrm{O}\right), 108.68(\mathrm{C} 6), 112.36,115.67,118.39\left(\mathrm{C}=\underline{\mathrm{CH}}_{2}\right), 120.25,120.84(\underline{\mathrm{C}} \mathrm{H}-\mathrm{C} 4), 121.63$ (때CHC3), 127.01, 128.18 (C5), 130.75 (ㄷH-CHC4), 135.12 (ㅌH-C3), 135.57, 150.66, 157.49, $161.78(\mathrm{C} 2) . \mathrm{MS} \mathrm{m} / \mathrm{z}(\%): 347\left([\mathrm{M}+2]^{+}, 2\right), 345\left(\mathrm{M}^{+}, 12\right), 344$ (13), 265 (60), 225 (100), 171 (17). Anal. $\mathrm{C}_{17} \mathrm{H}_{13} \mathrm{BrO}_{3}$ : C, $\mathrm{H}$.

3,4-Benzo-5',8-dimethylfuro[3,2-g]coumarin (20). This compound was prepared from 19 $(1.0 \mathrm{~g}, 2.9 \mathrm{mmol})$ and $\mathrm{N}, \mathrm{N}$-diethylaniline, in the same way as $\mathbf{9}$ from $\mathbf{8}$. The crude product was purified by FC using hexane/ethyl acetate (6:1) as eluent, yielding pure 20 (397 mg, 52.0\%). Mp: 230-231 ${ }^{\circ} \mathrm{C}$. IR: $2925,1722,1610,1440,1115,850 .{ }^{1} \mathrm{H} \mathrm{NMR}\left(\mathrm{CDCl}_{3}\right): 2.45$ (d, $J=1.2 \mathrm{~Hz}, 3 \mathrm{H}$, Me-C5'), 2.55 (s, 3H, Me-C8), 6.60 (d, $J=1.2$ Hz, 1H, H-4'), 7.47 (m, 1H, Cㅍ-CHC3), 7.74 (m, 2H, C$-\mathrm{CHC} 4), 7.94$ (s, 1H, H-5), 8.11 (d, J=8.0 Hz, 1H, CH-C4), 8.32 (d, J = 8.0 Hz, 1H,

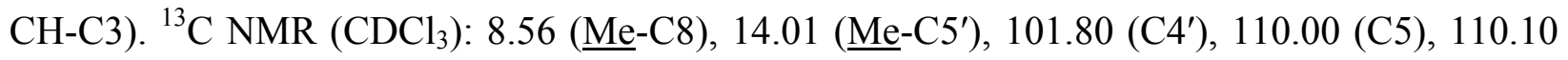

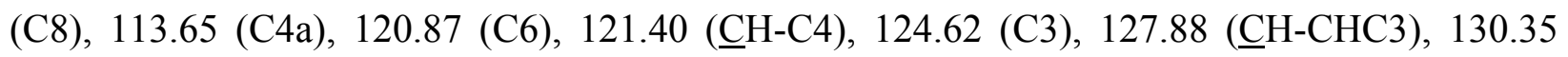

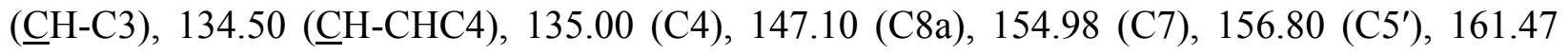
(C2). MS m/z (\%): $265\left([\mathrm{M}+1]^{+}, 15\right), 264\left(\mathrm{M}^{+}, 100\right), 235$ (19), 207 (10), 178 (17), 152 (10). Anal. $\mathrm{C}_{17} \mathrm{H}_{12} \mathrm{O}_{3}$ : C, H.

Photobiological methods. Cell cultures. HL-60 and HeLa cells were grown in RPMI 1640 (Sigma Chemical Co.) supplemented with 15\% heat-inactivated fetal calf serum (Biological Industries) and Nutrient Mixture F-12 [HAM] (Sigma Chemical Co.) supplemented with 10\% heat-inactivated fetal calf serum (Biological Industries), respectively. $100 \mathrm{U} / \mathrm{mL}$ penicillin, $100 \mu \mathrm{g} / \mathrm{mL}$ streptomycin and $0.25 \mu \mathrm{g} / \mathrm{mL}$ amphotericin B (Sigma Chemical Co.) were added to both media. The cells were cultured at $37^{\circ} \mathrm{C}$ in a moist atmosphere of $5 \%$ carbon dioxide in air.

Irradiation procedure. Irradiations were performed by means of Philips HPW 125 lamps equipped with a Philips filter emitting over $90 \%$ at $365 \mathrm{~nm}$. Irradiation intensity was checked on a UV-X radiometer (Ultraviolet Products Inc., Cambridge, UK) for each experimental procedure. Inhibition growth assays. HeLa cells $\left(10^{5}\right)$ were seeded into each well of a 24 -well cell culture plate. After incubation for $24 \mathrm{~h}$, the medium was replaced with an equal volume of Dulbecco's modified Eagle medium (DMEM, Sigma Chemical Co.) without phenol red, and various concentrations of the test agent were added. One hour later the cells were irradiated with a UVA 
dose of $0.793 \mathrm{~J} \mathrm{~cm}^{-2}$. After irradiation, the medium containing the compounds was removed, and the cells were incubated in complete F-12 medium for 24 hours.

HL-60 cells $\left(10^{5}\right)$ were seeded into each well of a $24-$ well cell culture plate. After incubation for 24 hours, various concentrations of the test agents were added in complete medium. The cells were kept in the dark for 1 hour, irradiated with a UVA dose of $0.793 \mathrm{~J} \mathrm{~cm}^{-1}$ and then incubated for a further 24 hours.

In the case of the experiments carried out in the dark, the cells, both HeLa and HL-60 were seeded $\left(10^{5}\right)$ and incubated for 24 hours. Then the test agents were added and the cells were incubated for a further 24 hours.

A trypan blue assay was performed to determine cell viability. Cytotoxicity data were expressed as $\mathrm{IC}_{50}$ values, i.e., the concentrations of the test agent inducing $50 \%$ reduction in cell numbers compared with control cultures.

Skin phototoxicity. Skin phototoxicity was tested on depilated albino guinea pigs (outbred Dunkin-Hartley strain), as previously reported. ${ }^{27}$ An ethanol solution of each new compound was applied topically to the skin up to $50 \mu \mathrm{g} / \mathrm{cm}^{2}$. For 8-MOP the concentration used was $10 \mu \mathrm{g} / \mathrm{cm}^{2}$. The animals were then kept in the dark for $45 \mathrm{~min}$ and the treated skin was irradiated with $20 \mathrm{~kJ} \mathrm{~m}^{-2}$ of UVA; erythema was scored after $48 \mathrm{~h}$.

Nucleic acid. Salmon testes DNA was purchased from Sigma Chemical Company (Cat. D1626). Its hypochromicity, determined according to Marmur and Doty, ${ }^{28}$ was over $35 \%$. The DNA concentration was determined using extinction coefficient $6600 \mathrm{M}^{-1} \mathrm{~cm}^{-1}$ at $260 \mathrm{~nm}$.

Preparation of adducts. Volumes of concentrated solutions of the examined compound were added to salmon testes DNA in ETN solution $\left(1.5 \times 10^{-3} \mathrm{M}\right)$ to achieve a DNA/compound ratio of about 80. The mixture was irradiated in a glass dish with four Philips HPW 125 lamps, arranged two above and two below the dish, at a distance of $7 \mathrm{~cm}$, for $120 \mathrm{~min}$ at room temperature. After irradiation the DNA was precipitated with $\mathrm{NaCl}$ (up to $1 \mathrm{M}$ concentration) and cool ethanol (2 volumes), the precipitated DNA was collected, washed with $80 \%$ ethanol, dried and then dissolved in a measured volume of buffer. The final solution was made $0.5 \mathrm{~N}$ with $\mathrm{HCl}$, heated at $100{ }^{\circ} \mathrm{C}$ for $2 \mathrm{~h}$, neutralised and extracted exhaustively with $\mathrm{CHCl}_{3}$. After this procedure the organic layers were collected, dried under high vacuum and dissolved in ethanol and the adduct was separated on TLC plates and eluted with 100\% ethanol. UV spectra were recorded on a Perkin Elmer model Lambda 5 spectrophotometer. The ${ }^{1} \mathrm{H}$ and ${ }^{13} \mathrm{C}$ assignment was obtained by utilising HMQC and HMBC spectra on a Bruker Avance DMX600 instrument. Mass spectrometry measurements were performed on a ElectroSpray Ionization (ESI) Time of Flight (ToF) instrument (mod. Mariner, Perseptive-Biosystem) by dissolving the samples in water/acetonitrile/formic acid (50:49:1) solution.

Photoreversal of adducts. Ethanol solution of the adduct (ca. $20 \mu \mathrm{g} / \mathrm{mL}$ ) was irradiated in quartz cuvettes with a mineral lamp $(254 \mathrm{~nm})$. The photosplitting reaction was followed spectrophotometrically. 
Evaluation of interstrand cross-links in vitro. Evaluation of cross-links was carried out by measuring the renaturation capacity of cross-linked double helix after thermal denaturation. Aliquots of aqueous solutions of salmon testes DNA (Sigma Co.), alone and at [nucleic acid $] /[\mathrm{drug}]=75$, were introduced into calibrated glass tubes, immersed in a thermostatically controlled bath, and then irradiated for various periods of time. After irradiation the samples were thermally denatured $\left(95^{\circ} \mathrm{C}\right.$ for $\left.15 \mathrm{~min}\right)$ and quickly cooled in ice. The renaturation capacity of DNA, due to cross-link formation, was investigated by recording absorbance at $260 \mathrm{~nm}$. Data were expressed in terms of non-renaturated fraction of irradiated compound-DNA complex relative to irradiated DNA, as suggested by Blais et al. ${ }^{29}$ In detail:

$$
N R F \%=100 \times \frac{\left(A_{\mathrm{R}}-A_{N}\right)_{\text {modified DNA }}}{\left(A_{\mathrm{R}}-A_{N}\right)_{\text {native DNA }}}
$$

where $A_{N}$ and $A_{R}$ are, respectively, the optical densities measured at $260 \mathrm{~nm}$ of DNA before heat denaturation and after renaturation. The calculated NRF\% values were expressed as log.

\section{Acknowledgments}

The authors are grateful to Mr. Mariano Schiavon for his skilful technical assistance.

\section{References}

1. Parrish, J. A.; Fitzpatrick, T. B.; Tannenbaum, L.; Pathak, M.A. N. Engl. J. Med. 1974, 291, 1207.

2. Lowe, N. J.; Chizhevsky, V.; Gabriel, H. Clin. Dermatol. 1997, 15, 745.

3. Bethea, D.; Fullmer, B.; Syed, S.; Seltzer, G.; Tiano, J.; Rischko, C.; Gillespie, L.; Brown, D.; Gasparro, F. P. J. Dermatol. Sci. 1999, 19, 78.

4. Edelson, R. L. Am. N. Y. Acad. Sci. 1991, 636, 154.

5. Van Iperen, H. P.; Beijersbergen van Henegouwen G. M. J. J. Photochem. Photobiol B: Biol. 1997, 39, 99.

6. McNeely, W.; Goa, K. L. Drugs 1998, 56, 667.

7. Pathak, M. A.; Fitzpatrick, T. B. J. Photochem. Photobiol. B. 1992, 14, 3.

8. Song, P.-S.; Tapley, K. J. Jr. Photochem. Photobiol. 1979, 29, 1177.

9. Rodighiero, P.; Palumbo, M.; Marciani Magno, S.; Manzini, P.; Gia, O.; Piro, R.; Guiotto, A. J. Heterocycl. Chem. 1986, 44, 1405.

10. Palumbo, M.; Rodighiero, P.; Gia, O.; Guiotto, A.; Marciani Magno, S. Photochem. Photobiol. 1986, 44, 1.

11. Gia, O.; Mobilio, S.; Palumbo, M.; Pathak, M. A. Photochem. Photobiol. 1993, 57, 497. 
12. Gia, O.; Conconi, M. T.; Uriarte, E. Farmaco. 1997, 5, 289.

13. Chilin, A.; Marzano, C.; Guiotto, A.; Manzini, P.; Baccichetti, F.; Carlassare, F.; Bordin, F. J. Med. Chem. 1999, 42, 2936.

14. Dalla Via, L.; Gia, O.; Marciani Magno, S.; Santana, L.; Teijera, M.; Uriarte E. J. Med. Chem. 1999, 42, 4405.

15. Dalla Via, L.; Uriarte, E.; Quezada, E.; Dolmella, A.; Ferlin, M. G.; Gia, O. J. Med. Chem. 2003, 46, 3800.

16. Dalla Via, L.; Gia, O.; Viola, G.; Bertoloni, G.; Santana, L.; Uriarte, E. Farmaco. 1998, 53, 638.

17. Dall'Acqua, F.; Marciani, S.; Vedaldi, D.; Rodighiero, G. Biochim. Biophys. Acta 1974, 353, 267.

18. Palumbo, M.; Baccichetti, F.; Antonello, C.; Gia, O.; Capozzi, A.; Marciani Magno, S. Photochem. Photobiol. 1990, 52, 533.

19. Gia, O.; Uriarte, E.; Zagotto, G.; Baccichetti, F.; Antonello, C.; Marciani Magno, S. J. Photochem. Photobiol. B: Biol. 1992, 14, 95.

20. Garazd, M. M.; Garazd, Ya. L.; Shilin, S. V.; Panteleimonova, T. N.; Khilya, V. P. Chem. Nat. Compd. 2002, 38, 230.

21. Confalone, P. N.; Confalone, D. L. Tetrahedron 1983, 39, 1265.

22. Garazd, Ya. L.; Ogorodniichuk, A. S.; Garazd, M. M.; Khilya, V. P. Chem. Nat. Compd. 2002, 38, 424.

23. Dall'Acqua, F.; Terbojevich, M.; Marciani S.; Vedaldi D.; Recher M. Chem.-Biol. Interact. 1978, 21, 103.

24. Caffieri, S.; Rodighiero, P.; Vedaldi, D.; Dall'Acqua, F. Photochem. Photobiol. 1985, 42, 361.

25. Dall'Acqua, F.; Vedaldi, D.; Baccichetti, F.; Rodighiero, G.; Gennaro, A. QSAR In Design Of Bioactive Compounds; M. Kuchar: Barcelona, 1984.

26. Miranda, R.; Santana, L.; Uriarte, E.; Zagotto, G. Spectrochim. Acta 1994, 50A, 161.

27. Gia, O.; Anselmo, A; Conconi, M. T.; Antonello, C.; Uriarte, E.; Caffieri, S. J. Med. Chem. 1996, 39, 4489.

28. Marmur, J.; Doty, P. J. Mol. Biol. 1962, 5, 109.

29. Blais, J.; Vigny, P.; Moron, J.; Bisagni, E. Photochem. Photobiol. 1984, 39, 145. 